Check for updates

Cite this: Mater. Adv., 2020 1, 1952

Received 21st June 2020 Accepted 28th July 2020

DOI: 10.1039/d0ma00441c

rsc.li/materials-advances

\section{Improved catalytic effect and metal nanoparticle stability using graphene oxide surface coating and reduced graphene oxide for hydrogen generation from ammonia-borane dehydrogenation $\dagger$}

\author{
Samikannu Prabu (D) and Kung-Yuh Chiang (D) * \\ The development of high catalytic effective catalysts for hydrogen generation through dehydrogenation \\ (hydrolysis) of aqueous $\mathrm{NH}_{3} \mathrm{BH}_{3}$ (AB) solution is discussed in this work. Bimetallic NiPt, CoPt and \\ monometallic Ni, Co, Pt nanoparticles (NPs) supported on mixed graphene oxide (GO) and reduced \\ graphene oxide $\mathrm{rGO}$ (carbon materials) were produced and studied for hydrogen generation from $A B$ \\ hydrolytic dehydrogenation. Herein, we have developed fine, spherically-shaped bimetallic and \\ monometallic $\mathrm{Ni}, \mathrm{Co}, \mathrm{Pt}$ NPs on mixed $\mathrm{GO}$ and $\mathrm{rGO}$ for extremely high reactant productivity in aqueous \\ $\mathrm{AB}$ hydrolysis. The $\mathrm{CO}_{0.8} \mathrm{Pt}_{0.2} / \mathrm{GO}$ and $\mathrm{rGO}, \mathrm{Ni}_{0.8} \mathrm{Pt}_{0.2} / \mathrm{GO}$ and $\mathrm{rGO}$ catalysts show high catalytic \\ performance and high turnover frequency (TOF) of 230.76 and $214.28\left(\mathrm{H}_{2}\right) \mathrm{mol}$. (cat. metal) $\mathrm{mol}^{-1} \mathrm{~min}^{-1}$ \\ at $25{ }^{\circ} \mathrm{C}$. This is the greatest efficiency ever shown for transition metal-doped GO and rGO catalysts. \\ The catalysts additionally show superior catalytic stability by maintaining up to $98 \%$ activity after 7 runs \\ at $25^{\circ} \mathrm{C}$. The development of well-organized and inexpensive $\mathrm{Co}_{0.8} \mathrm{Pt}_{0.2} / \mathrm{GO}$ and $\mathrm{rGO}, \mathrm{Ni}_{0.8} \mathrm{Pt}_{0.2} / \mathrm{GO}$ and \\ rGO catalysts improve the possibility of using aqueous $A B$ as chemical hydrogen storage. This permits \\ the discovery of additional hydrogen fuel-cell applications. The simple and facile production of other \\ GO and rGOs can assist in transition metal NPs.
}

\section{Introduction}

The rapid consumption and decrease of fossil fuels have pushed the focus towards economical energy techniques for producing hydrogen gas. Hydrogen gas is a wonderful energy carrier that addresses the difficulties in energy conservation and future energy alternatives. Still, after several years of development, the $\mathrm{H}_{2}$ storage efficiency is one of the interesting barriers in hydrogen generation techniques. Characteristic $\mathrm{H}_{2}$ storage in chemicals mixtures, such as formic acid $(\mathrm{HCOOH})$, hydrous hydrazine $\left(\mathrm{N}_{2} \mathrm{H}_{4} \cdot \mathrm{H}_{2} \mathrm{O}\right)$, methanol $\left(\mathrm{CH}_{3} \mathrm{OH}\right)$, and ammonia borane $\left(\mathrm{NH}_{3} \mathrm{BH}_{3}\right)$ has the hydrogen limit of $4.4,8.0,18.8$, and $19.6 \mathrm{wt} \%$, respectively. $\mathrm{AB}$ is a remarkable $\mathrm{H}_{2}$ storage catalyst due to its high hydrogen content (19.6 wt\%), high durability in the liquid state at room temperature $\left(25{ }^{\circ} \mathrm{C}\right)$, and non-toxicity. ${ }^{1,2}$ It can also generate hydrogen quickly at room temperature $\left(\right.$ at $25{ }^{\circ} \mathrm{C}$ ) in a safe system by the use of catalysts, which is truly a reasonable method for hydrogen generation from $\mathrm{AB}$ solution. ${ }^{3}$ Effective

Graduate Institute of Environmental Engineering, National Central University, Tao-Yuan city, 32001, Taiwan. E-mail: kychiang@ncu.edu.tw

$\dagger$ Electronic supplementary information (ESI) available. See DOI: 10.1039/ d0ma00441c catalysts are normally built from suitable metals (such as, Pt $\mathrm{Pd}, \mathrm{Au}$, and $\mathrm{Ru}),{ }^{4}$ which profoundly constrain economical applications. Hence, research in non-conventional metalbased catalysts for $\mathrm{AB}$ hydrolysis in the generation of hydrogen is really important.

Some transition metal NPs have shown amazing catalytic efficiencies. ${ }^{5,6}$ Therefore, studying the reasonable relationship between the catalytic performance and the metal support is essential. The quantitative recognition of the nature of metal-support interfaces in the absence of detailed information on hydrolysis reaction and catalytic active sites remains a field of interest. The established hydrolysis reaction methods under homogeneous catalysis cannot be straightforwardly connected to heterogeneous catalysis in the presence of the phase interface and complex active sites in heterogeneous catalysis. $^{7}$

Hydrogen generation by means of thermal decomposition, for example, aqueous $\mathrm{AB}$ solution hydrolysis in the presence of an acceptable catalyst produces three moles of hydrogen gas per mole of $\mathrm{AB}$ solution at $25{ }^{\circ} \mathrm{C}$ (eqn (1)). This makes it a compelling catalyst for hydrogen generation from $\mathrm{AB}$.

$$
\mathrm{NH}_{3} \mathrm{BH}_{3}(\mathrm{aq})+2 \mathrm{H}_{2} \mathrm{O}(\mathrm{l}) \rightarrow \mathrm{NH}_{4}+(\mathrm{aq})+\mathrm{BO}_{2}-(\mathrm{aq})+3 \mathrm{H}_{2}(\mathrm{~g})
$$


For the most part, $\mathrm{Pt},{ }^{8-12} \mathrm{Ru},{ }^{13-15}$ and $\mathrm{Pd}^{16}$ based catalysts outshine non-noble metals, such as Ni, Cr, ${ }^{17} \mathrm{Co},{ }^{18-20} \mathrm{RuPd} @ G O,{ }^{21}$ $\mathrm{Ag} / \mathrm{Pd},{ }^{22,23} \mathrm{Fe},{ }^{24,25} \mathrm{Ag}-\mathrm{Ni}$ based nanoparticles, ${ }^{26} \mathrm{Au}-\mathrm{Pd},{ }^{27}$ mesoporous carbon nitride supported $\mathrm{Pd}$ and $\mathrm{Pd}-\mathrm{Ni} \mathrm{NPs},{ }^{28} \mathrm{PdNi}-$ $\mathrm{CeO}_{2},{ }^{29} \mathrm{NiPt}$ NPs with supported $\mathrm{CeO}_{2}{ }^{30}$ (efficient hydrogen generation from an alkaline solution of hydrazine), N-doped graphene supported $\mathrm{Co}-\mathrm{CeOx},{ }^{31}$ and transition metal nanoparticles with $\mathrm{GO}^{32}$ for hydrogen generation under the above conditions. Though there has been development in the catalytic efficiencies of bimetallic catalysts, for example, Co-Pd ${ }^{33,34}$ and core-shell species such as Au@Co, ${ }^{35}$ and monometallic catalysts, the general utilization of these noble metals is restricted by their high cost and the extraordinary amount required. To solve this issue, the search for abundant metal catalysts with durable catalytic activities that can be utilized at $25{ }^{\circ} \mathrm{C}$ is very urgent and essential.

One useful surface approach is to modulate the contribution of active metal NPs. A single-atom two-dimensional material exhibits interesting properties, such as a high specific surface area, high catalytic efficiency, fine and spherically-shaped particles, and conserved charge transfer, and is, therefore, an ideal substrate for the advancement and affixing of metal NPs such as, graphene, GO, and carbon nanotubes. ${ }^{36,37}$ In spite of the staggering expense of graphene, graphene-supported metal NPs have become noteworthy supports because of their potential applications in a few specialized areas such as catalysis, devices, and energy conversion. ${ }^{38}$ Of late, metal oxides such as $\mathrm{TiO}_{2}, \mathrm{SnO}_{2}, \mathrm{Fe}_{3} \mathrm{O}_{4}, \mathrm{SiO}_{2}$, and $\mathrm{CeO}_{2}$ have been commonly utilized as catalyst promoters to build reactant stability and metal nanocatalyst activity. ${ }^{39}$ Among the examined metal oxides, the rare-earth metal oxide $\mathrm{CeO}_{2}$ is of considerable importance because of its rich oxygen defects, high oxygen storage capacity, and cost-effectiveness. ${ }^{40-45}$ In this situation, the presence of an $\mathrm{M} / \mathrm{CeO}_{2}$ /graphene triple convergence with the $\mathrm{CeO}_{2}$ mixture, a metal, and graphene may potentially produce a catalyst with remarkably improved catalytic activity for the dehydrogenation of aqueous $\mathrm{AB}$ as well as dispensability in the catalytic process.

Herein, we report a green and facile preparation for the synthesis of well-dispersed $\mathrm{Co}_{0.8} \mathrm{Pt}_{0.2} / \mathrm{GO}$ and $\mathrm{rGO}, \mathrm{Ni}_{0.8} \mathrm{Pt}_{0.2} / \mathrm{GO}$ rGO catalysts that were utilized for catalytic hydrogen generation from $\mathrm{AB}$ hydrolytic dehydrogenation at $25{ }^{\circ} \mathrm{C}$. Incredibly, the prepared noble-metal $\mathrm{Co}_{0.8} \mathrm{Pt}_{0.2} / \mathrm{GO}$ and $\mathrm{rGO}, \mathrm{Ni}_{0.8} \mathrm{Pt}_{0.2} / \mathrm{GO}$ and rGO catalysts demonstrate higher catalytic performance, $100 \%$ hydrogen selectivity, and strong durability for hydrogen generation from $\mathrm{AB}$, with 3 equivalents per mmole of $\mathrm{AB}$ generated within 0.6 and $0.5 \mathrm{~min}$, respectively. The CoPt/GO and rGO, NiPt/GO and rGO catalysts demonstrate that they have the most important role in improving the metal NP catalytic efficiency. Because of the synergistic effect among CoPt and NiPt NPs supported on GO and rGO and the strong metal-support interface between the metals and the supporter, the prepared $\mathrm{Co}_{0.8} \mathrm{Pt}_{0.2} / \mathrm{GO}$ and $\mathrm{rGO}, \mathrm{Ni}_{0.8} \mathrm{Pt}_{0.2} / \mathrm{GO}$ and $\mathrm{rGO}$ catalysts showed greater catalytic efficiency for hydrogen generation from aqueous $\mathrm{AB}$ solution, with TOF of 230.76 and $214.28 \mathrm{~min}^{-1}$ at $25{ }^{\circ} \mathrm{C}$, respectively.

\section{Experimental section}

\subsection{Chemicals and reagents}

Graphite, sodium nitrate $\left(\mathrm{NaNO}_{3}\right)$ (Fischer synthetic chemicals), sulfuric acid $\left(\mathrm{H}_{2} \mathrm{SO}_{4}\right)$ (Sigma Aldrich), potassium permanganate $\left(\mathrm{KMnO}_{4}\right)$, hydrogen peroxide $\left(\mathrm{H}_{2} \mathrm{O}_{2}\right)$, cobalt(II) nitrate hexahydrate $\left(\mathrm{Co}\left(\mathrm{NO}_{3}\right)_{2} \cdot 6 \mathrm{H}_{2} \mathrm{O}\right)$, nickel(II) nitrate hexahydrate $\left(\mathrm{Ni}\left(\mathrm{NO}_{3}\right)_{2} \cdot 6 \mathrm{H}_{2} \mathrm{O}\right)$, chloroplatinic corrosive hexahydrate $\left(\mathrm{H}_{2} \mathrm{PtCl}_{6}\right)$, and ammonia borane $\left(\mathrm{NH}_{3} \mathrm{BH}_{3}\right)$.

\subsection{Graphene oxide (GO) preparation}

In the characteristic synthetic method, pure graphite powder was first oxidized using a modified Hummers' procedure to procure graphene oxide (GO). In this strategy, $2 \mathrm{~g}$ of graphite powder and one gram of sodium nitrate $\left(\mathrm{NaNO}_{3}\right)$ were mixed in $40 \mathrm{~mL}$ sulfuric acid solution $\left(\mathrm{H}_{2} \mathrm{SO}_{4}\right)$ (Sigma Aldrich) under continuous magnetic stirring for $3 \mathrm{~h}$ at room temperature. Eight grams of potassium permanganate $\left(\mathrm{KMnO}_{4}\right)$ was then added slowly into the solution and the solution was constantly stirred until it turned a dull dark color. Deionized (DI) water $(100 \mathrm{~mL})$ was delicately added to the solution and the solution was kept at $70{ }^{\circ} \mathrm{C}$ for $30 \mathrm{~min}$. Finally, $250 \mathrm{~mL}$ of DI water was added to remove the excess of $\mathrm{KMnO}_{4}$. Next, $0.675 \mathrm{~mL}$ of hydrogen peroxide $\left(\mathrm{H}_{2} \mathrm{O}_{2}\right)$ was added slowly and continuously stirred for $15 \mathrm{~min}$. Next, hydrochloric acid and $\mathrm{H}_{2} \mathrm{O}$ in the $1: 3$ ratio were added and centrifuged utilizing a Table Top Centrifuge at $7000 \mathrm{rpm}$ for $5 \mathrm{~min}$. At that point, the supernatant was washed with DI water a few times. The washed GO supernatant was dried utilizing a stove at $70{ }^{\circ} \mathrm{C}$ for $24 \mathrm{~h}$ to obtain the graphene oxide powder.

\subsection{Metal-doped GO and rGO NP preparation}

CoNi@GO and rGO, CoPt@GO and rGO, NiPt@GO and rGO, Pt@GO,Co@GO, Ni@GO,0.2 g of GO, and 0.0049 M urea were suspended in $20 \mathrm{~mL}$ of DI water and sonicated to obtain the dispersed GO solution. $5 \mathrm{~mL}$ of an aqueous solution containing $\mathrm{Co}\left(\mathrm{NO}_{3}\right)_{2} \cdot 6 \mathrm{H}_{2} \mathrm{O}(0.1 \mathrm{M})$, and $\mathrm{Ni}\left(\mathrm{NO}_{3}\right)_{2} \cdot 6 \mathrm{H}_{2} \mathrm{O}$ and $\mathrm{H}_{2} \mathrm{PtCl}_{6}$ $(0.012 \mathrm{M})$ was added into the above solution and sonicated for $5 \mathrm{~min}$. Subsequently, the solution was transferred into a $50 \mathrm{~mL}$ Teflon-lined stainless-steel autoclave. The autoclave was fixed and heated at $180{ }^{\circ} \mathrm{C}$ for $5 \mathrm{~h}$ in an oven. Accordingly, after the hydrothermal reaction, the acquired product was gathered through centrifugation and washed with DI water five times. The final product M@GO and rGO ( $\mathrm{M}-\mathrm{Co}, \mathrm{Ni}$, and $\mathrm{Pt}$ ) was obtained after it was dried under an oxygen environment at $70{ }^{\circ} \mathrm{C}$ for $24 \mathrm{~h}$. The product M@GO and rGO was also toughened with calcination at $500{ }^{\circ} \mathrm{C}$ for $1 \mathrm{~h}$. The final composition of the catalysts was determined by ICP-AES (Table S1, ESI $\dagger$ ). This scheme led to the synthesis of $\mathrm{Co}_{0.4} \mathrm{Ni}_{0.6} / \mathrm{GO}, \mathrm{Co}_{0.6} \mathrm{Ni}_{0.4} /$ $\mathrm{GO}, \mathrm{Co}_{0.8} \mathrm{Pt}_{0.2} / \mathrm{GO}$, and $\mathrm{Ni}_{0.8} \mathrm{Pt}_{0.2} / \mathrm{GO}$ catalysts.

\subsection{Characterization}

Powder X-ray diffraction (XRD) patterns were obtained utilizing a Bruker D8 PHASER X-ray diffractometer with GO monochromatized $\mathrm{Cu} \mathrm{K} \alpha$ radiation $(\lambda=1.5406 \AA)$ at a scanning rate of $5^{\circ} \min ^{-1}$. The microstructure and particle sizes of the catalysts 
were obtained from a transmission electron microscope (TEM). A field emission scanning electron microscope (FESEM, JEOL JSM 7600F) along with an energy dispersive X-ray detector (EDX) was utilized for investigating the morphology and FT-IR spectroscopy was used for identifying the hydrogen and oxygen molecular cell arrangements.

\subsection{AB hydrogenation}

Reaction devices were utilized for hydrogen generation from aqueous $\mathrm{AB}$ solution hydrolysis. Typically, the solution $(10 \mathrm{~mL})$ with the catalyst was placed in a two-necked round bottom flask. A hydrogen gas burette filled with water was linked with one neck of the reaction flask (the other neck was shut with a stopper) to determine the volume $(\mathrm{mL})$ of hydrogen gas. The reaction flask temperature was kept steady at $25{ }^{\circ} \mathrm{C}$ using a flowing water bath under ambient atmosphere. The catalytic reaction was activated once $2 \mathrm{mmol}$ of the $\mathrm{AB}(0.0686 \mathrm{~g})$ solution was added into the reaction flask using a syringe. The volume of $\mathrm{H}_{2}$ generated was determined by recording the water displacement in the gas burette, as shown in Fig. S1 (ESI $\dagger$ ). The reaction was considered to be complete when $\mathrm{H}_{2}$ generation was observed.

The above method was also utilized for characterizing the catalytic efficiency of other catalysts for $\mathrm{H}_{2}$ generation from aqueous $\mathrm{AB}$ solution hydrolysis. The $n \mathrm{M} / \mathrm{AB}$ molar ratio for each one of the reactions was maintained at $0.04 \mathrm{M}$. The improvement in the catalytic performance over the $\mathrm{Ni}_{0.8} \mathrm{Pt}_{0.2} / \mathrm{GO}$ and rGO (optimum catalyst), $\mathrm{Co}_{0.8} \mathrm{Pt}_{0.2} / \mathrm{GO}$ and rGO NPs was observed at various temperatures $(278 \mathrm{~K}, 283 \mathrm{~K}, 288 \mathrm{~K}, 293 \mathrm{~K}$, $298 \mathrm{~K}$, and $303 \mathrm{~K}$ ) to determine the actuation energy $\left(E_{\mathrm{a}}\right)$ for the aqueous $\mathrm{AB}$ hydrolysis reaction. An equivalent procedure was additionally helpful to for determining the catalytic performance of the catalytic reaction with $100 \mathrm{mg}$ of nanoparticles as the catalyst in the presence of different added substances $(\mathrm{NaOH}$, $\mathrm{KOH}, \mathrm{NaH}_{2} \mathrm{PO}_{4}, \mathrm{NH}_{4} \mathrm{OH}$, and $\left.\mathrm{NaCl}\right)$. However, the above-mentioned substances were added prior to adding the aqueous $\mathrm{AB}$ solutions into the reaction flask.

\subsection{Durability test}

For the durability test, after the catalytic hydrolysis reaction of the aqueous $\mathrm{AB}$ solution was completed, the catalyst was kept in the reaction flask and a further aliquot of aqueous $\mathrm{AB}$ solution ( $2 \mathrm{mmol}(0.0686 \mathrm{~g})$ ) was consequently added to it. The catalyst recovery tests for aqueous $\mathrm{AB}$ solution hydrolysis were carried out for 10 runs at $25{ }^{\circ} \mathrm{C}$.

\subsection{Calculation method}

The turnover frequency (TOF) values described at this time equal the TOF values established from the number of metal atoms in the catalyst, as calculated from eqn (S1):

$$
\mathrm{TOF}=n \mathrm{H}_{2} /(n \mathbf{M} \times t)
$$

where $n \mathrm{H}_{2}$ is the number of moles of hydrogen, $n \mathrm{M}$ is the number of moles of metal in the catalyst, and $t$ is the reaction time (min).

\section{Results and discussion}

\subsection{Structure and morphology}

An advanced chemical reduction method was utilized for the combination of Ni-Pt/GO, Co-Pt, and Ni-Co NPs (Scheme 1). Typically, for the preparation of $\mathrm{Ni}_{0.8} \mathrm{Pt}_{0.2} / \mathrm{GO}$ and $\mathrm{rGO}, \mathrm{Co}_{0.8} \mathrm{Pt}_{0.2} /$ $\mathrm{GO}$ and $\mathrm{rGO}, \mathrm{Co}\left(\mathrm{NO}_{3}\right)_{2} \cdot 6 \mathrm{H}_{2} \mathrm{O}(0.1 \mathrm{M})$, and $\mathrm{Ni}\left(\mathrm{NO}_{3}\right)_{2} \cdot 6 \mathrm{H}_{2} \mathrm{O}$ and $\mathrm{H}_{2} \mathrm{PtCl}_{6}(0.012 \mathrm{M})$ were mixed with $5 \mathrm{~mL}$ of an aqueous solution containing highly dispersed GO $(0.2 \mathrm{~g})$ and the above solution was sonicated for $5 \mathrm{~min}$. The solution was moved to a $50 \mathrm{~mL}$ Teflon-lined stainless-steel autoclave. The autoclave was fixed and heated at $180{ }^{\circ} \mathrm{C}$ for $5 \mathrm{~h}$ in an oven. After completion, $\mathrm{Ni}_{0.8} \mathrm{Pt}_{0.2} / \mathrm{GO}$ and $\mathrm{rGO}, \mathrm{Co}_{0.8} \mathrm{Pt}_{0.2} / \mathrm{GO}$ and $\mathrm{rGO}$ NPs were obtained as the products and were utilized as catalysts for

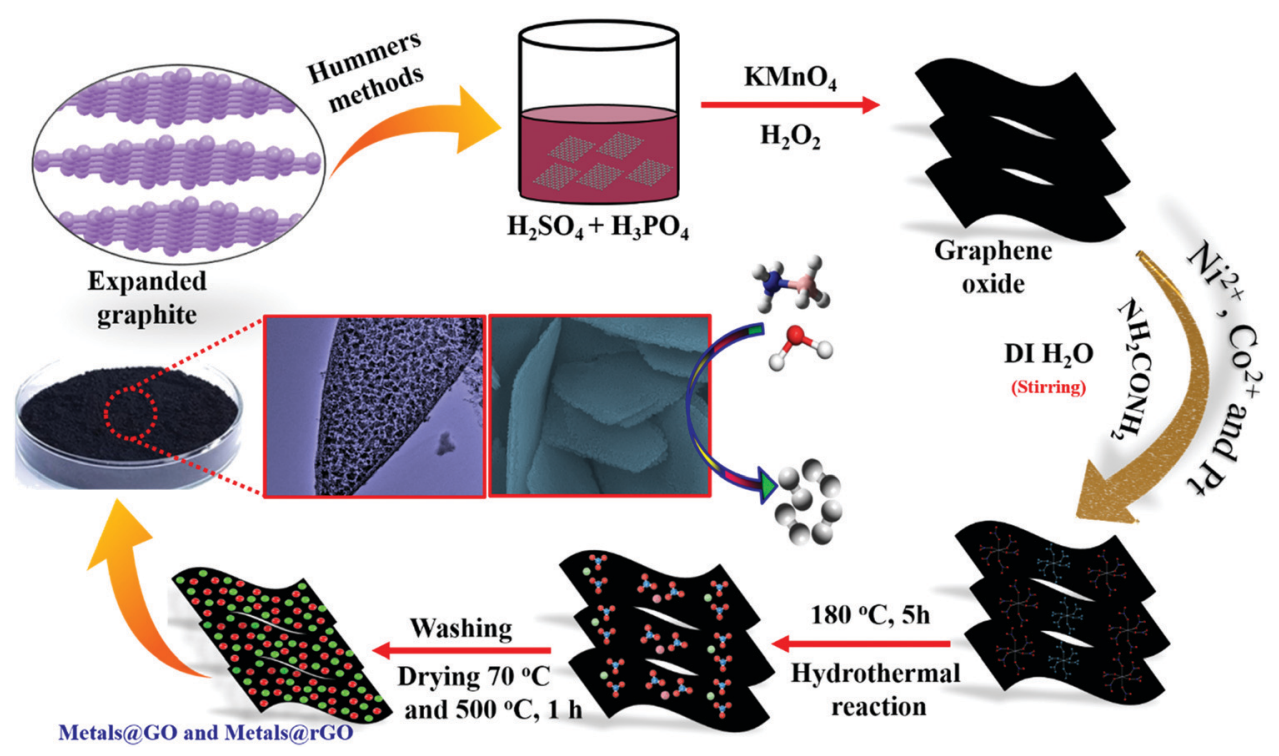

Scheme 1 The synthetic process of metals $\mathrm{GGO}$ and $\mathrm{rGO}$ nanosheets (M-Co, Ni, and Pt). 
hydrogen generation from $\mathrm{AB}$ hydrolysis at $25{ }^{\circ} \mathrm{C}$ (for details, see the Experimental section).

The $\mathrm{Ni}_{0.8} \mathrm{Pt}_{0.2} / \mathrm{GO}$ and $\mathrm{rGO}, \mathrm{Co}_{0.8} \mathrm{Pt}_{0.2} / \mathrm{GO}$ and rGO NPs morphologies were characterized using scanning electron microscopy (FESEM) and transition electron microscopy (TEM) images, as shown in Fig. 1. The process can be seen in Fig. 1b; NiPt NPs with fine and small sizes of about $1.5 \mathrm{~nm}$ (Fig. 1c) are well-spread onto the GO and rGO sheets, as shown by the FESEM result (Fig. 1a). In any case, the synthesized CoPt/GO and rGO NPs have a small, spherically-shaped particle size of about $1.9 \mathrm{~nm}$ (Fig. $1 \mathrm{~b}^{\prime}$ and $\mathrm{c}^{\prime}$ ). By observing the TEM images of $\mathrm{Ni}_{0.8} \mathrm{Pt}_{0.2} / \mathrm{GO}$ and $\mathrm{rGO}$ NPs, $\mathrm{Co}_{0.8} \mathrm{Pt}_{0.2} / \mathrm{GO}$ and rGO NPs, it can be clearly seen that $\mathrm{CoO}$ doping into the NiO NPs can cause a decrease in the metal NP sizes. In order to further investigate, the metal-doped GO NPs obtained with a different $(\mathrm{Co}+\mathrm{Ni})$ molar ratio are named as CoNi/GO. The typical FESEM and TEM images of the obtained CoNi/GO catalysts are demonstrated in Fig. S3 (ESI $\dagger$ ). The nanosheet shape of GO is wide-ranging and uniform after the CoNi NPs are loaded via the reduction reaction. It can be seen from the FESEM (Fig. S3a, ESI $\dagger$ ) and bright-field TEM (Fig. S3b, ESI $\dagger$ ) images that the CoNi NPs acquired through the rapid reduction process $(\mathrm{Co}+\mathrm{Ni})$ are highly distributed into the $\mathrm{Co}_{0.6} \mathrm{Ni}_{0.4} / \mathrm{GO}$ and $\mathrm{Co}_{0.4} \mathrm{Ni}_{0.6} / \mathrm{GO}$ NPs. The mean particle sizes are about $3.2 \mathrm{~nm}$ and $4.2 \mathrm{~nm}$ (Fig. S3c and f, ESI $\dagger$ ), respectively, with further evidence of the existence of $\mathrm{Co}, \mathrm{Ni}$, and $\mathrm{Pt}$ in the doped samples. EDX was used to observe the elemental composition of the doped samples. After the EDX spectroscopy investigation, the results obtained reveal that the samples are composed of $\mathrm{C}, \mathrm{O}, \mathrm{Co}, \mathrm{Ni}$, and $\mathrm{Pt}$ elements that are found in all the catalysts and the total compositional atomic percentages of $\mathrm{C}, \mathrm{O}, \mathrm{Co}, \mathrm{Ni}$, and $\mathrm{Pt}$ were estimated. Table summarizes (inside the EDX spectrum) the elements in the nanostructures (Fig. S4, ESI $\dagger$ ) and the occurrence of $\mathrm{Ni}, \mathrm{Co}, \mathrm{C}$, and $\mathrm{O}$ was recognized by elemental mapping (Fig. S5 and S6, ESI $\dagger$ ). It can be obviously seen that the distribution of $\mathrm{Ni}$, Co, C, and $\mathrm{O}$ elements is very consistent with that shown in the FESEM images.

For investigating the feasibility of the NPs, we observed and associated the monometallic Pt/GO and $\mathrm{Co} / \mathrm{GO}$ catalyst microstructure in the as-prepared catalysts. The TEM images of monometallic $\mathrm{Pt} / \mathrm{GO}$ and $\mathrm{Co} / \mathrm{GO}$ show that separate $\mathrm{Pt} / \mathrm{GO}$ and Co/GO NPs are homogeneously dispersed on GO with an average particle size of about $4.3 \mathrm{~nm}$ and $30.2 \mathrm{~nm}$ (Fig. S7, $\mathrm{ESI} \dagger)$, respectively. The particle sizes of the Pt and Co NPs in this study are smaller. Histograms of the NPs were achieved by including at least 50 particles. The Pt and Co NPs size of the $\mathrm{Pt} / \mathrm{GO}$ catalyst is about $4.3 \mathrm{~nm}$, whereas the Co size of the $\mathrm{Co} / \mathrm{GO}$ catalyst is distributed at about $30.2 \mathrm{~nm}$. The mean particle size of Pt/GO is smaller than that of the Co/GO NPs.

Fig. 2 demonstrates the characteristic powder-XRD patterns of the as-obtained GO and rGO and the metal mixtures. All the peaks could be correlated with the face-centered cubic (fcc) structures. The first graphene oxide (GO) sample demonstrated a strong diffraction peak centered at $2 \theta=13.01$, corresponding to an interlayer spacing of about $0.76 \mathrm{~nm}$, compared to the (001) reflection of graphene oxide, which is broader than that of pristine graphite. After surface doping, the metal-doped (Ni, Co, and Pt) GO revealed negligible C (001) peaks compared to GO. For the metal-doped materials after minor heat treatment, the GO peak widened and the rGO $(2 \theta=26.39)(022)$ peak plane with an interlayer spacing of about $0.34 \mathrm{~nm}$ was obtained, representing the reduction of graphene oxide to rGO. The GO peak broadens on exposure to high temperature. Furthermore, as observed from the XRD pattern in Fig. 2, the diffraction peaks
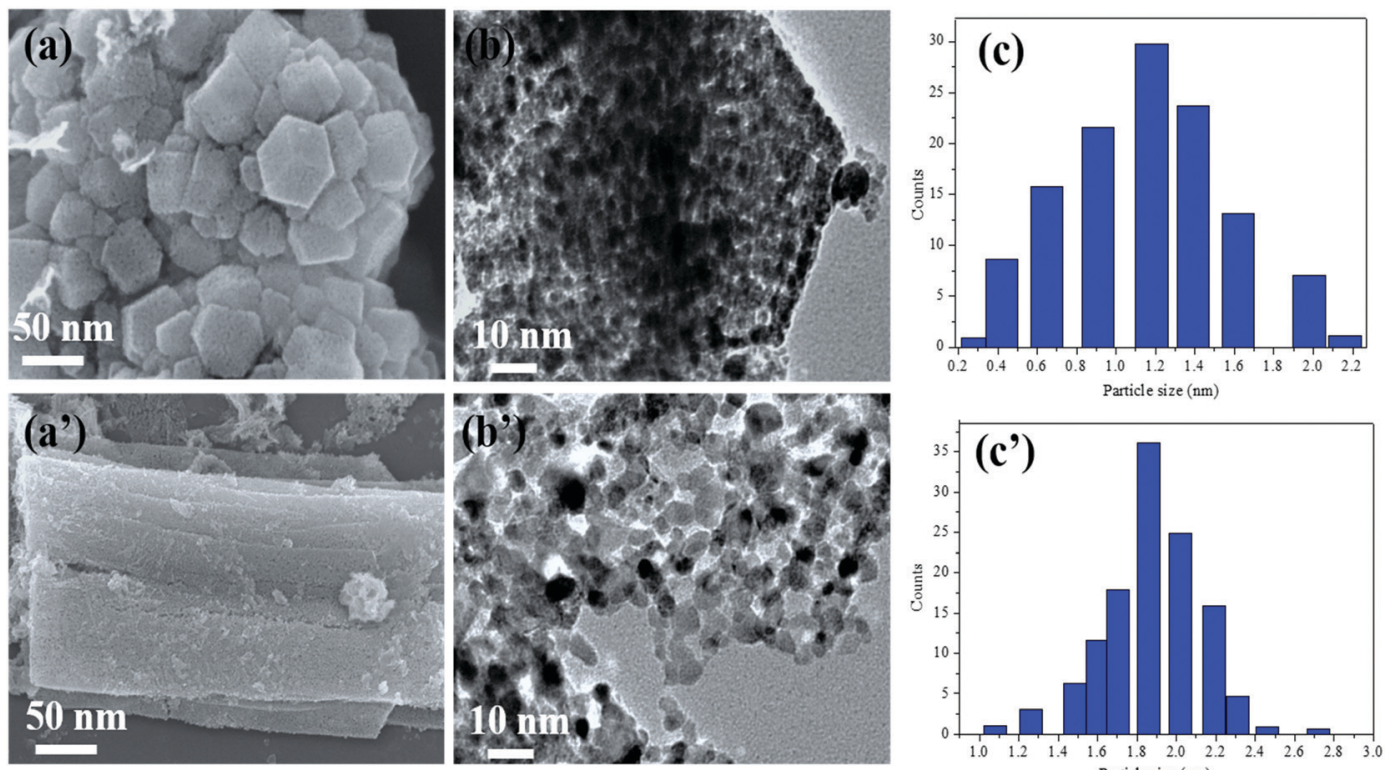

Fig. 1 FE-SEM and TEM images of the as-synthesized $\mathrm{Ni}_{0.8} \mathrm{Pt}_{0.2} / \mathrm{GO}$ and $\mathrm{rGO} \mathrm{NPs}$ (a) and $\mathrm{Co}_{0.8} \mathrm{Pt}_{0.2} / \mathrm{GO}$ and $\mathrm{rGO} \mathrm{NPs}\left(\mathrm{a}^{\prime}\right.$ ). TEM images (b) of $\mathrm{Ni}_{0.8} \mathrm{Pt}_{0.2} / \mathrm{GO}$ and $\mathrm{rGO}$ NPs and $\left(\mathrm{b}^{\prime}\right) \mathrm{CO}_{0.8} \mathrm{Pt}_{0.2} / \mathrm{GO}$ and $\mathrm{rGO}$. The inset in (c) and $\left(\mathrm{c}^{\prime}\right)$ are the average particle size distribution of $\mathrm{Ni}_{0.8} \mathrm{Pt}_{0.2} / \mathrm{GO}$ and $\mathrm{rGO}$ $\mathrm{CO}_{0.8} \mathrm{Pt}_{0.2} / \mathrm{GO}$ and $\mathrm{rGO}$, respectively. 


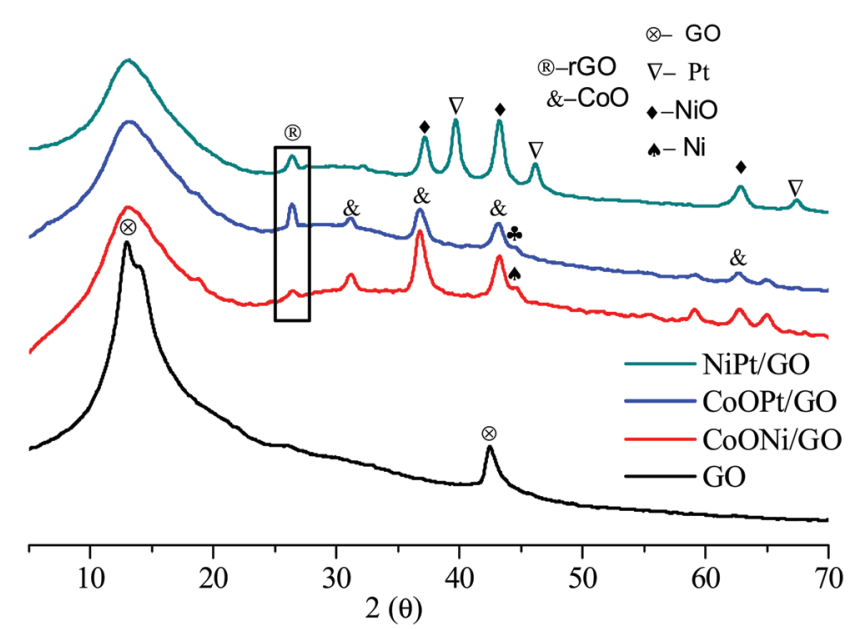

Fig. 2 The typical XRD patterns of the as-prepared GO nanosheet (a), $\mathrm{CoNi} / \mathrm{GO}$ and rGO, (b), CoOPt/GO and rGO (c), and NiPt/GO and rGO NPs.

at $2 \theta=39.64^{\circ}, 46.36^{\circ}$, and $67.55^{\circ}$ could be indexed to the characteristic (111), (200), and (220) planes of the cubic crystalline structured Pt, respectively. The NiO and CoO (PDF\#96-9008619 ) peaks are very strong for Co support to that $\mathrm{NiO}, \mathrm{CoO}$ is improved detached on the GO, and rGO support with smaller and fine particles demonstrating their high crystallinity. These observed results clearly confirm the formation of the $\mathrm{Ni}$, Co, and Pt/GO NPs. Moreover, the wide peaks at $31.16^{\circ}, 36.64^{\circ}$, and $59.14^{\circ}$ were likewise observed for the three metal oxides, representing the formation of rGO and GO doped with metal NPs. Compared with the monometallic catalysts, the bimetallic catalysts were determined to undergo considerably more structural alteration and therefore, a greater number of active sites were created om them for the catalytic reactions.

Raman spectroscopy was used to further distinguish the reduction of GO, with two prominent peaks at 1338.26 and $1594 \mathrm{~cm}^{-1}$ conforming to the $\mathrm{D}$ and $\mathrm{G}$ bands of the $\mathrm{C}$ atomic crystals, respectively. The peaks for the NiPt/GO and rGO, CoPt/ GO and rGO catalysts were red-shifted to 1339.06, 1346.48 and $1598.74,1596.86 \mathrm{~cm}^{-1}$ for the $\mathrm{D}$ and $\mathrm{G}$ bands, respectively, after $1 \mathrm{~h}$ reduction at $500{ }^{\circ} \mathrm{C}$, as shown in Fig. 3. The D-peak represents the defects in the lattice of the $\mathrm{C}$ atom, while the G-peak in-plane stretching vibration represents the $\mathrm{sp}^{2}$ hybridization of the $\mathrm{C}$ atom. Furthermore, the $\mathrm{D} / \mathrm{G}$ intensity ratio was significantly broadened after reduction, from 0.83 for GO to 0.84 and 0.84 for NiPt/GO and rGO, CoPt/GO and rGO after $1 \mathrm{~h}$ reduction, representing that large amounts of graphitic carbon were present in the samples, respectively. The red-shift of the $\mathrm{G}$ band and an increase in the $\mathrm{D} / \mathrm{G}$ intensity ratio both indicate the increase in the $\mathrm{sp}^{2}$ carbon regions.

\subsection{Catalytic hydrolysis of aqueous $\mathrm{AB}$}

To evaluate the catalytic efficiency of the catalysts, the hydrolysis of $\mathrm{AB}$ catalyzed by $\mathrm{M} / \mathrm{GO}$ and $\mathrm{rGO}(\mathrm{M}-\mathrm{Co}, \mathrm{Ni}$, and $\mathrm{Pt}$ ) was examined. The hydrogen generation curves are shown in Fig. 4. $\mathrm{Ni}_{0.8} \mathrm{Pt}_{0.2} / \mathrm{GO}$ and $\mathrm{rGO}, \mathrm{Co}_{0.8} \mathrm{Pt}_{0.2} / \mathrm{GO}$ and $\mathrm{rGO}$ NPs completed the hydrolysis reaction within 0.5 and $0.6 \mathrm{~min}$ at $25{ }^{\circ} \mathrm{C}$,

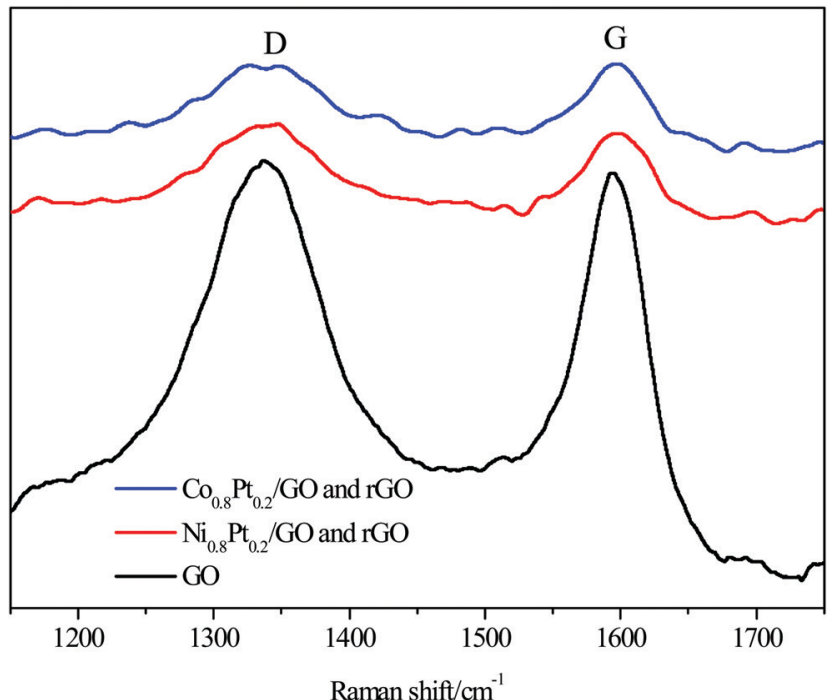

Fig. 3 Raman spectra for GO, NiPt/GO and rGO, and CoPt/GO and rGO.

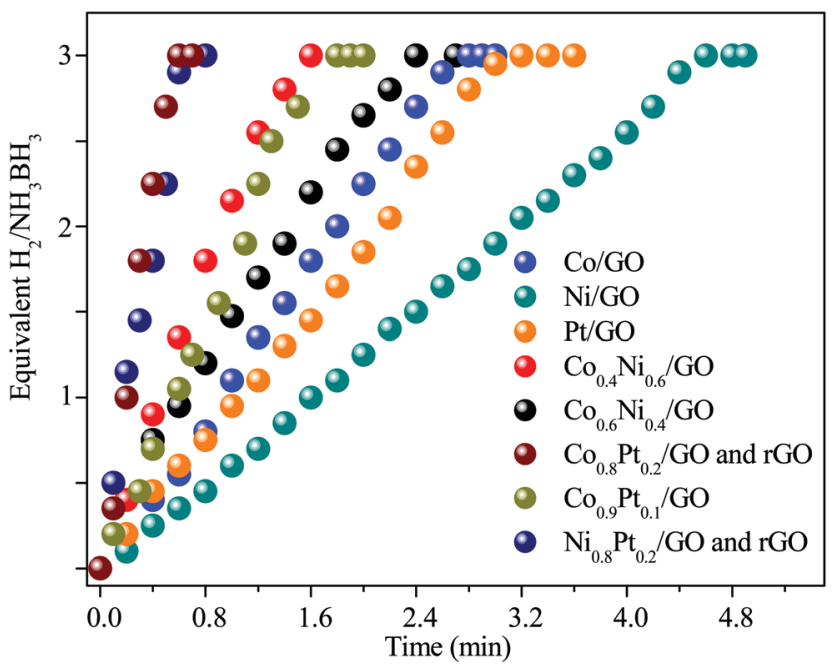

Fig. 4 Hydrogen productivity vs. reaction time for hydrogen release from an aqueous $A B$ solution ( $100 \mathrm{mM}, 10 \mathrm{~mL}$ ) catalyzed by $\mathrm{M} / \mathrm{GO}$ and $\mathrm{rGO}$ $(\mathrm{M}-\mathrm{Co}, \mathrm{Ni}$, and $\mathrm{Pt})$ at $298 \mathrm{~K}(n \mathrm{Ni} / n \mathrm{AB}=0.04)$.

respectively, and exhibited higher catalytic efficiency than monometallic Ni/GO, Co/Pt, and pure materials. To determine the optimal ratio of $\mathrm{Pt} / \mathrm{Co}$ for $\mathrm{Co}_{0.8} \mathrm{Pt}_{0.2} / \mathrm{GO}$ and rGO NPs, a series of composite catalysts with constant Pt content were prepared. Their catalytic activities show a volcano-shaped change with increasing Pt/Co ratios, as shown in Fig. 4, and reach a peak value at a certain Pt/Co ratio. Further increasing the Co content ([Co]) led to a sharp decrease in the activity. GO and rGO without metal doping showed an improvement over the organized progressive nanostructure, while the contact between GO and rGO enhanced the dispersion of metal NPs. This energy is obtained due to the reduced amount of loaded Ni, Co, and $\mathrm{Pt}$ NPs, which were fundamental for the catalytic hydrolysis of $\mathrm{AB}$. The presence of $\mathrm{Ni}_{0.8} \mathrm{Pt}_{0.2} / \mathrm{GO}$ and $\mathrm{rGO}, \mathrm{Co}_{0.8} \mathrm{Pt}_{0.2} / \mathrm{GO}$ and rGO NPs assisted in the production of well-scattered and ultrafine metal 
NPs and increased the loading amount of the metal NPs. The activity was maintained as the amount of Pt metal increased to $0.3 \mathrm{wt} \%$ and $0.5 \mathrm{wt} \%$ but decreased when the added amount of $\mathrm{Pt}$ metal reached $5 \mathrm{wt} \%$, which may be attributed to the thick Pt shell that prevents the diffusion and hydrolysis of $\mathrm{AB}$ molecules on the surface of the nanoparticles. Optimal catalytic activity can be realized on a catalytic surface with median binding energies of the reactive intermediates. If the reactant binds to the catalyst surface too weakly, then it cannot be activated. However, if it binds to the surface too strongly, it will occupy all the available surface sites and poison the catalyst. Thus, it is believed that there is an optimal $\mathrm{Pt} / \mathrm{Co}$ ratio for achieving the highest catalytic activity for the hydrolysis of the $\mathrm{AB}$ complex. Monometallic Ni/GO, $\mathrm{Co} / \mathrm{GO}$, and Pt/GO NPs showed slightly less catalytic efficiency for $\mathrm{AB}$ hydrolysis due to their hierarchical nanostructure. These effects demonstrate that the arranged hierarchical nanostructure required an increase in the catalytic performance of the $\mathrm{B}-\mathrm{H}$ bond. Other catalysts, including Ni/GO, did not display promising catalytic efficiencies. Subsequently, $\mathrm{Ni}_{0.8} \mathrm{Pt}_{0.2} / \mathrm{GO}$ and $\mathrm{rGO}$, $\mathrm{Co}_{0.8} \mathrm{Pt}_{0.2} / \mathrm{GO}$ and $\mathrm{rGO} \mathrm{NPs}$ performed as the main catalytic species in $\mathrm{AB}$ hydrolysis. The best catalyst was chosen considering the $\mathrm{H}_{2}$ selectivity and the amount of Ni, Co, and Pt NPs loaded. The optimized $\mathrm{Ni}_{0.8} \mathrm{Pt}_{0.2} / \mathrm{GO}$ and $\mathrm{rGO}, \mathrm{Co}_{0.8} \mathrm{Pt}_{0.2} / \mathrm{GO}$ and rGO NPs exhibited the highest TOF value of 230.76 and $214.28 \mathrm{~min}^{-1}$ for $\mathrm{AB}$ hydrolysis, respectively, as shown in Fig. 5 and Table S2 (ESI $\dagger$ ).

Various supports changed the structures, bringing about different catalytic performances. At that point, the absorbent inorganic catalysts, $\mathrm{Al}_{2} \mathrm{O}_{3}$ and $\mathrm{SiO}_{2}$, were utilized as supports for the synthesis of $\mathrm{Ni}$ and Co NP catalysts using a similar method to that for NiPt/GO and rGO. The TEM images show that the Ni and Co NPs in NiPt $/ \mathrm{Al}_{2} \mathrm{O}_{3}, \mathrm{CoNi} / \mathrm{Al}_{2} \mathrm{O}_{3}$, and NiPt/ $\mathrm{SiO}_{2}$ likewise have a small size (Fig. S8, ESI $\dagger$ ). However, they were greater than those of NiPt/GO and rGO. The synergistic catalysts in $\mathrm{NiPt} / \mathrm{Al}_{2} \mathrm{O}_{3}, \mathrm{CoNi} / \mathrm{Al}_{2} \mathrm{O}_{3}$, and $\mathrm{NiPt} / \mathrm{SiO}_{2}$ showed lower reactant dehydrogenation than NiPt/GO and rGO (Fig. 6) but

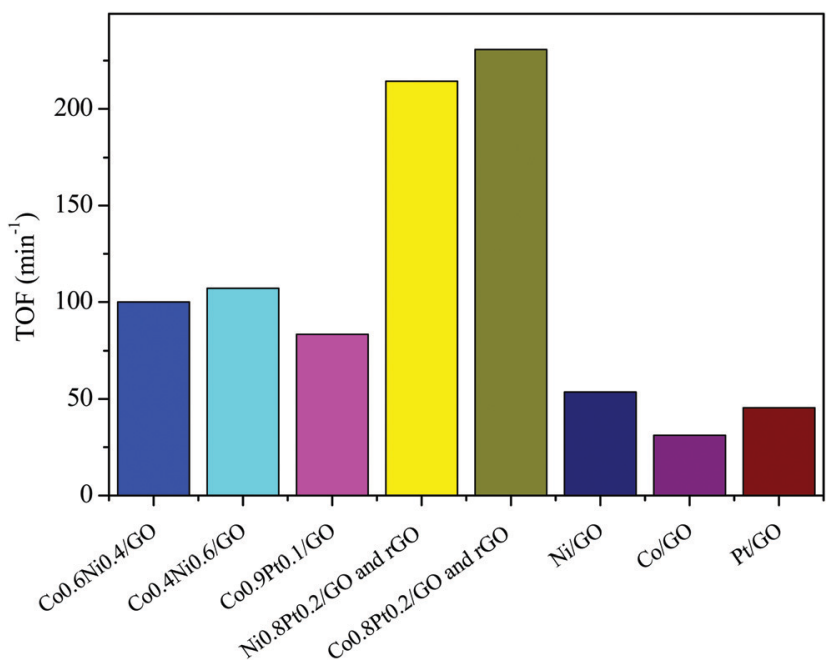

Fig. 5 The corresponding TOF values for the dehydrogenation of ammonia borane solution (100 mM, $10 \mathrm{~mL}$ ) catalyzed by M/GO and $\mathrm{KGO}(\mathrm{M}-\mathrm{Co}, \mathrm{Ni}$, and Pt) at $298 \mathrm{~K}(n \mathrm{Ni} / n \mathrm{AB}=0.04)$.
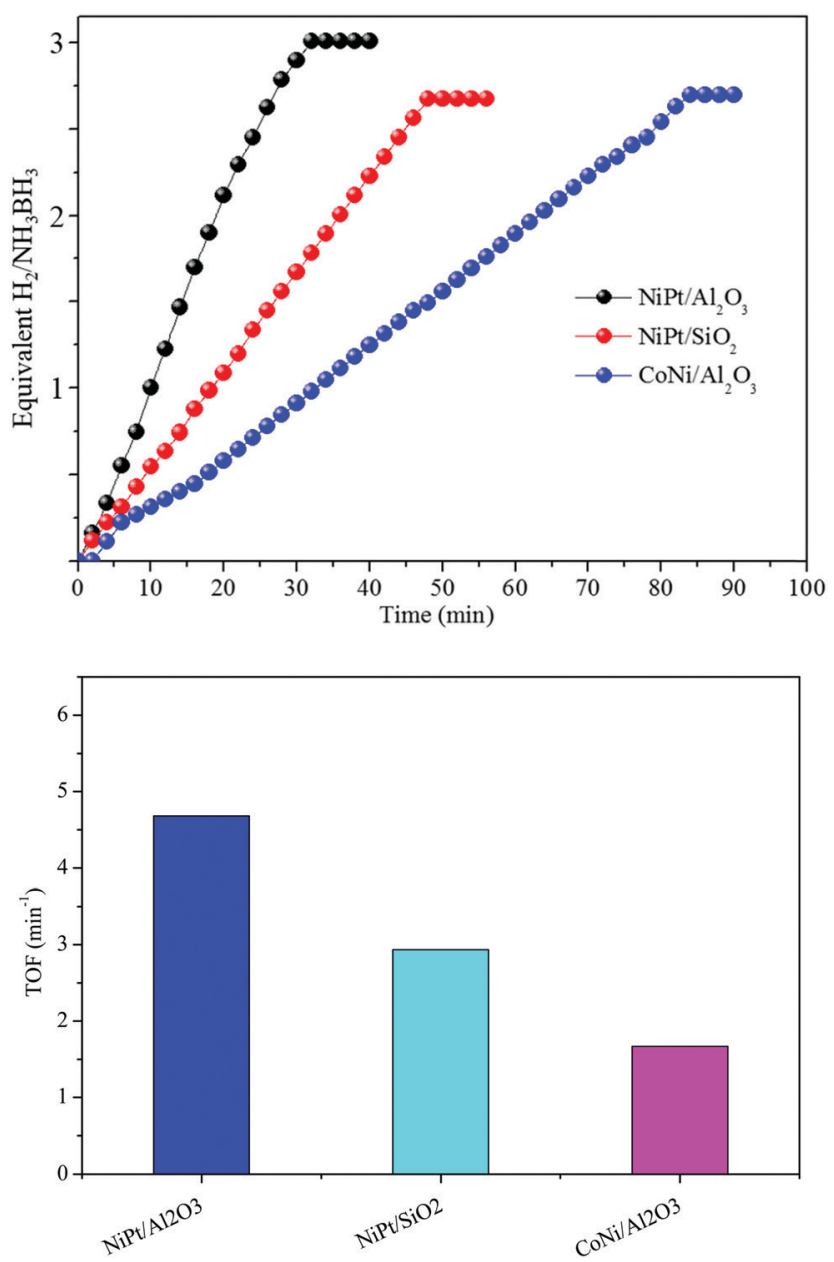

Fig. 6 Plots of time versus hydrogen generation volume from the $\mathrm{NH}_{3} \mathrm{BH}_{3}$ aqueous solution over (a) $\mathrm{NiPt} / \mathrm{Al}_{2} \mathrm{O}_{3}$, (b) $\mathrm{NiPt} / \mathrm{SiO}_{2}$, and (c) $\mathrm{CoNi} / \mathrm{Al}_{2} \mathrm{O}_{3}$, and the corresponding TOF values using different catalysts.

their catalytic performance was still higher than that of the other reported noble-metal free catalysts (Table S3, ESI $\dagger$ ). These distinctive catalyst efficiencies may be due to various materials, among which the high specific surface area of the metal NPs and the solid adsorption of $\mathrm{NH}_{3} \mathrm{BH}_{3}$ into their pores led to the quick reactant dehydrogenation of $\mathrm{AB}$. In addition, these consequences, including various types of supports, can be additionally attributed to the assumption of improved synergistic effect over amorphous metal NPs.

In addition, the detailed examination of the kinetic reaction for the aqueous $\mathrm{AB}$ hydrolysis reaction was undertaken by changing the number of catalysts with the similar amount of $\mathrm{AB}$ at room temperature $\left(25^{\circ} \mathrm{C}\right)$. Fig. $7 \mathrm{~A}$ shows the influence of the amount of catalyst on the catalytic hydrogen generation reaction, where the amount of $\mathrm{AB}$ was kept at $2 \mathrm{mmol}$ at $25{ }^{\circ} \mathrm{C}$ and the catalytic amounts were set at 20, 40, 60, 80, and $100 \mathrm{mg}$. We can see that the catalysts can effectively start the $A B$ complex hydrolysis. The hydrogen generation efficiency was improved with increasing catalyst amount within the measured range. Fig. 7B demonstrates the plot of moles of hydrogen generated versus the catalyst amount on a logarithmic scale. 

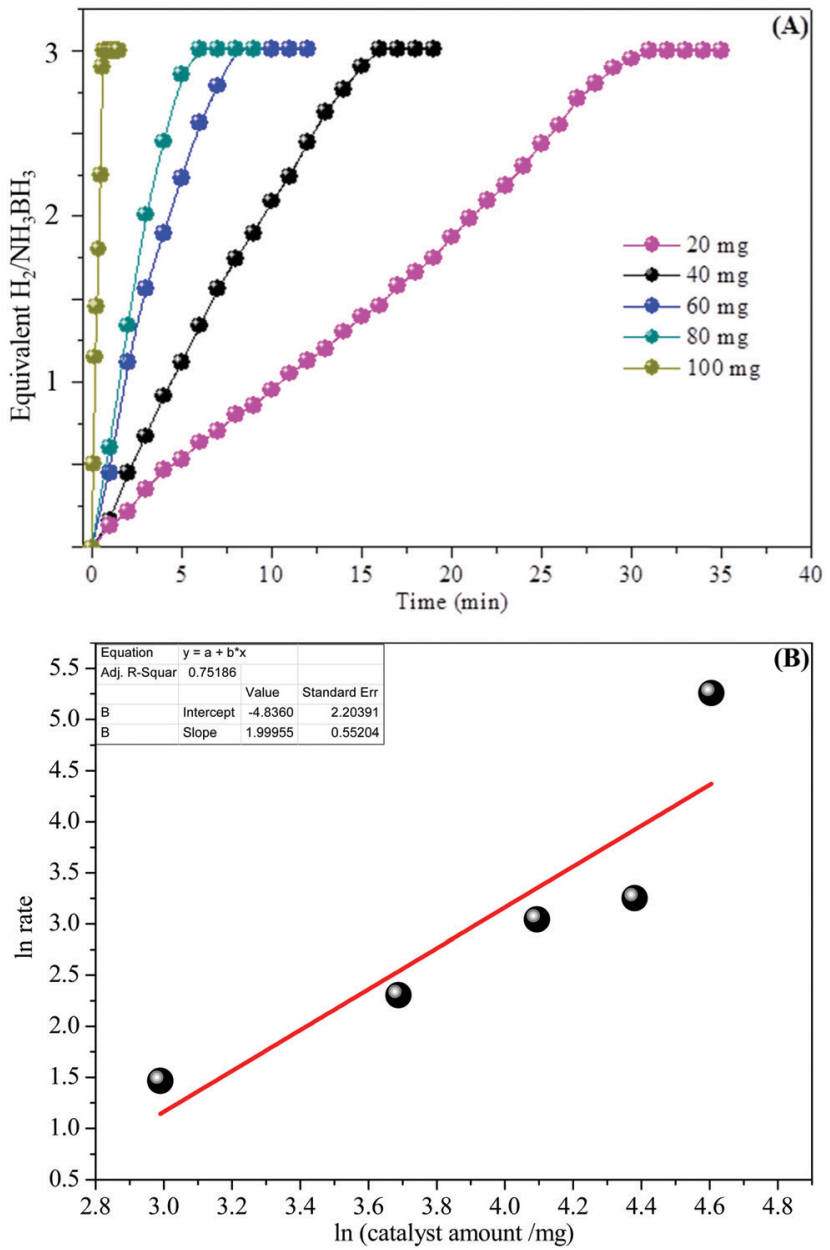

Fig. 7 (A) The effect of the catalyst amount on the hydrogen generation reaction. (B) The fitting plot of hydrogen generation rate vs. the catalyst amount, with both axes in a logarithmic scale (catalyst $\mathrm{Ni}_{0.8} \mathrm{Pt}_{0.2} / \mathrm{GO}$ and $\mathrm{rGO}$ ).

The slope of 1.99 shows that the catalytic hydrolysis reaction of aqueous $\mathrm{AB}$ is first-order with respect to the catalyst amount and the observation is in acceptable understanding.

\subsection{Kinetic study}

Fig. 8 demonstrates the plots of time versus the moles of hydrogen generated at various temperatures. For a known temperature, hydrogen is created directly in a stoichiometric volume of six moles. For the temperature rise from $25{ }^{\circ} \mathrm{C}$ to $60{ }^{\circ} \mathrm{C}$, hydrogen is generated rapidly, proposing quicker reaction kinetics. The reaction rate constant $(k)$ is determined by the condition (eqn (2)) below,

$$
\frac{-\mathrm{d}\left[\mathrm{NH}_{3} \mathrm{BH}_{3}\right]}{3 \mathrm{~d} t}=\frac{\mathrm{d}\left[\mathrm{H}_{2}\right]}{\mathrm{d} t}=k
$$

The activation energy is accordingly calculated from the Arrhenius equation (eqn (3)) between $\ln k$ and $1 / T$ as follows

$$
\ln k=\frac{-E_{\mathrm{a}}}{R t}\left[\frac{1}{T}\right]+\ln A
$$
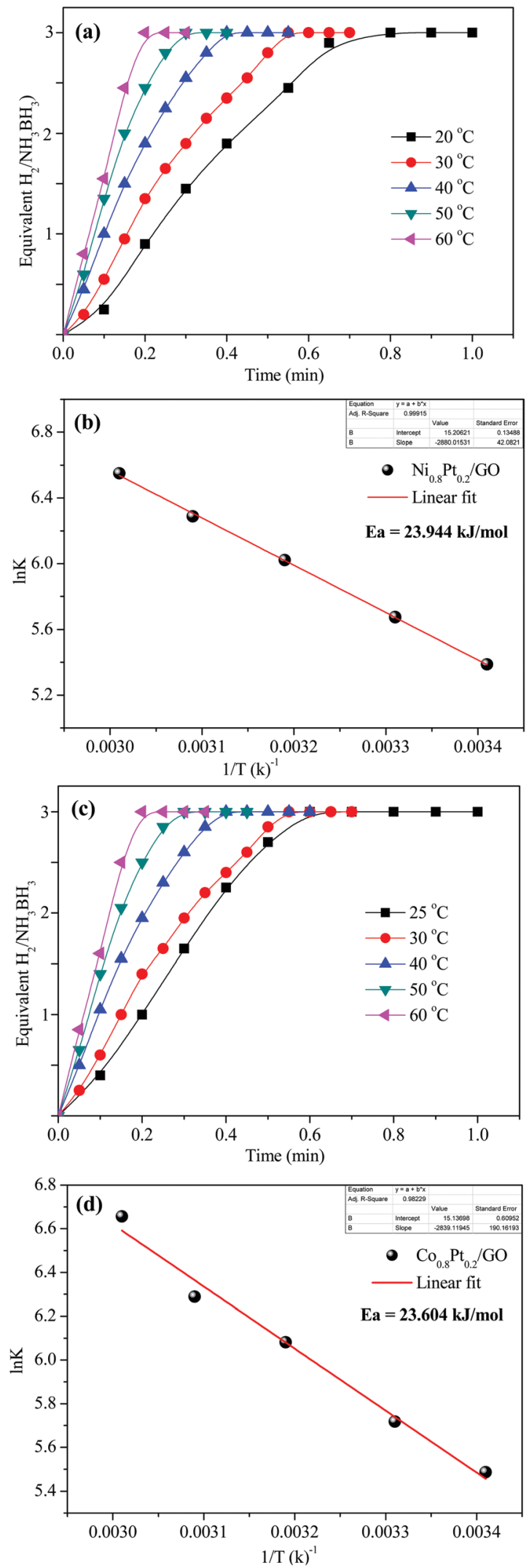

Fig. 8 (a and c) Plots of time versus hydrogen evolution catalyzed by $\mathrm{Ni}_{0.8} \mathrm{Pt}_{0.2} / \mathrm{GO}$ and $\mathrm{rGO}, \mathrm{Co}_{0.8} \mathrm{Pt}_{0.2} / \mathrm{GO}$ and $\mathrm{rGO}$ NPs at various temperatures; ( $\mathrm{b}$ and $\mathrm{d}$ ) corresponding Arrhenius plots ( $\ln k$ versus $1 / T$ ). 
where $E_{\mathrm{a}}$ is the activation energy, $R$ is the gas constant, $T$ is the absolute temperature in Kelvin, and $A$ is the pre-exponential factor.

To demonstrate the temperature effect on aqueous $\mathrm{AB}$ hydrolytic dehydrogenation, the kinetics of $\mathrm{Ni}_{0.8} \mathrm{Pt}_{0.2} / \mathrm{GO}$ and $\mathrm{rGO}, \mathrm{Co}_{0.8} \mathrm{Pt}_{0.2} / \mathrm{GO}$ and $\mathrm{rGO}$ catalyzed hydrogen generation were studied at different temperatures $\left(25-60{ }^{\circ} \mathrm{C}\right)$. Fig. $8 \mathrm{a}$ and c shows the hydrolytic dehydrogenation amount of $\mathrm{AB}$ catalyzed by $\mathrm{Ni}_{0.8} \mathrm{Pt}_{0.2} / \mathrm{GO}$ and $\mathrm{rGO}, \mathrm{Co}_{0.8} \mathrm{Pt}_{0.2} / \mathrm{GO}$ and $\mathrm{rGO}$ NPs. The reaction was carried out at increased temperature in the range of $25-60{ }^{\circ} \mathrm{C}$. The rate of the reaction is significantly improved on increasing the temperature. As indicated by the Arrhenius plot in Fig. $8 \mathrm{~b}$ and $\mathrm{d}$, the achieved activation energy $\left(E_{\mathrm{a}}\right)$ of $\mathrm{AB}$ hydrolysis catalyzed by $\mathrm{Ni}_{0.8} \mathrm{Pt}_{0.2} / \mathrm{GO}$ and $\mathrm{rGO}, \mathrm{Co}_{0.8} \mathrm{Pt}_{0.2} / \mathrm{GO}$ and rGO NPs is $23.94 \mathrm{~kJ} \mathrm{~mol}^{-1}$ and $23.60 \mathrm{~kJ} \mathrm{~mol}^{-1}$, respectively, which is lower than those of the recently reported noble-metal catalysts. ${ }^{31}$ As shown in Fig. S9 (ESI $\dagger$ ), the hydrogen generation rate increases with increasing temperature. The catalytic reactions for hydrogen generation from aqueous $\mathrm{AB}$ solution were completed in 0.6, 0.5, 0.4, 0.3, $0.2 \mathrm{~min}\left(\mathrm{Ni}_{0.8} \mathrm{Pt}_{0.2} / \mathrm{GO}\right.$ and $\left.\mathrm{rGO}\right)$, $0.62,0.55,0.42,0.33,0.21 \mathrm{~min}\left(\mathrm{Co}_{0.8} \mathrm{Pt}_{0.2} / \mathrm{GO}\right.$ and $\left.\mathrm{rGO}\right)$, and 25 ,
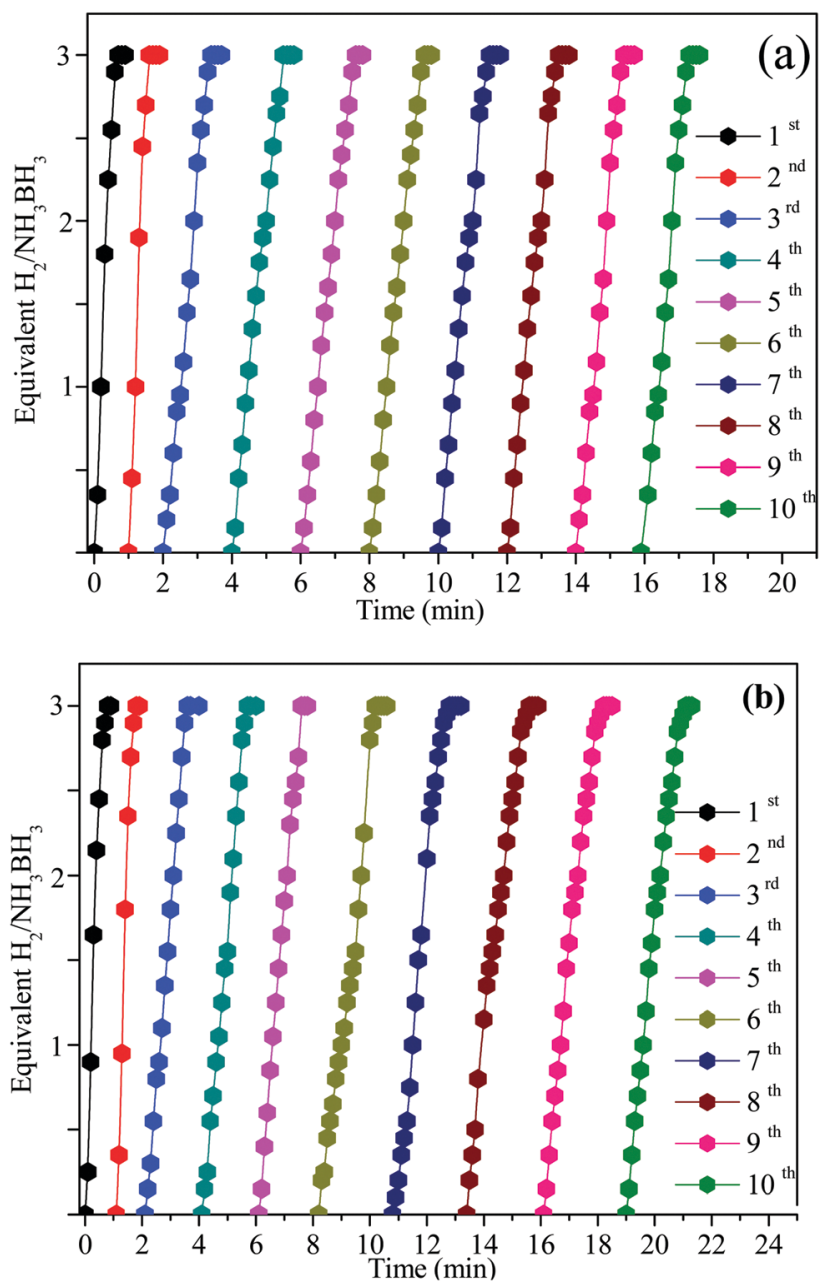

Fig. 9 Reusability of the $\mathrm{Ni}_{0.8} \mathrm{Pt}_{0.2} / \mathrm{GO}$ and $\mathrm{rGO}, \mathrm{Co}_{0.8} \mathrm{Pt}_{0.2} / \mathrm{GO}$ and $\mathrm{rGO}$ nanocatalysts for $A B$ hydrolysis for 10 successive cycles at $25^{\circ} \mathrm{C}$.
$30,40,50,60{ }^{\circ} \mathrm{C}$, whose corresponding TOF values are 214.0, 250.0, 333.3, 500.0 and $750.0 \mathrm{~min}^{-1}\left(\mathrm{Ni}_{0.8} \mathrm{Pt}_{0.2} / \mathrm{GO}\right.$ and $\left.\mathrm{rGO}\right)$, and 176.4, 230.7, 300.0, 428.5, $681.8 \mathrm{~min}^{-1}\left(\mathrm{Co}_{0.8} \mathrm{Pt}_{0.2} / \mathrm{GO}\right.$ and rGO) (Fig. S9, ESI $\dagger$ ).

Seeing the significance of the catalytic stability in practical application, the recyclability and stability of the $\mathrm{Ni}_{0.8} \mathrm{Pt}_{0.2} / \mathrm{GO}$ and $\mathrm{rGO}, \mathrm{Co}_{0.8} \mathrm{Pt}_{0.2} / \mathrm{GO}$ and $\mathrm{rGO}$ NPs were studied at $25{ }^{\circ} \mathrm{C}$ by adding the same amount of the $\mathrm{AB}$ solution. When the first cycle was completed, as shown in Fig. 9, the hydrogen generation volume was unaltered after 10 cycles. The initial activity was maintained, showing its great recyclability. However, the hydrogen generation amount displayed a slight decrease. After the stability test, the $\mathrm{Ni}_{0.8} \mathrm{Pt}_{0.2} / \mathrm{GO}$ and $\mathrm{rGO}, \mathrm{Co}_{0.8} \mathrm{Pt}_{0.2} / \mathrm{GO}$ and rGO NPs were then characterized by TEM. The TEM image of the used $\mathrm{Ni}_{0.8} \mathrm{Pt}_{0.2} / \mathrm{GO}$ and $\mathrm{rGO}, \mathrm{Co}_{0.8} \mathrm{Pt}_{0.2} / \mathrm{GO}$ and rGO NP catalysts clearly showed that no great change could be recognized for the morphology of the reused catalysts. The CoPt and NiPt NPs in the GO support were still well-scattered without the presence of clusters. The effective catalytic performance and stability can be similarly obtained with smaller-sized CoPt
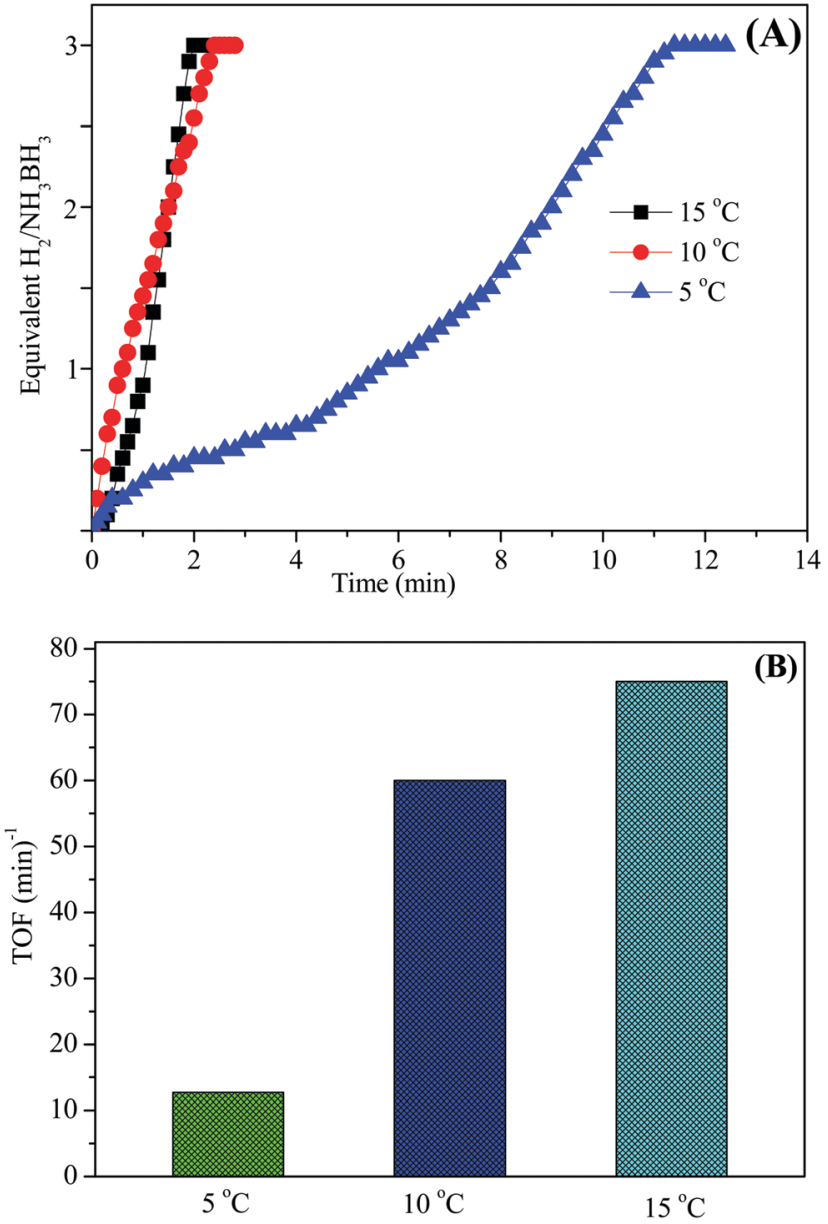

Fig. 10 (A) Hydrogen production as a function of time from $\mathrm{AB}$ aqueous solution over the as-prepared catalysts at different temperatures, (B) according to the TOF values for $A B$ hydrolysis at different temperatures in the range of $5-15^{\circ} \mathrm{C}$ (metal/AB $=0.04$ ). 


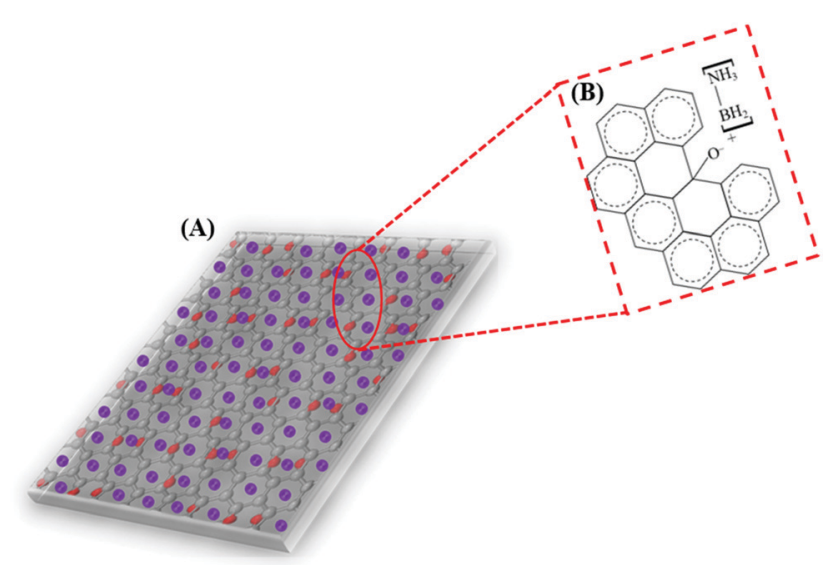

Fig. 11 (A) Schematic representation of the GO-AB nanostructure arrangement. (B) The point-by-point representation of the communication between the $A B$ cation and the oppositely charged oxygen from $G O$

and NiPt NPs. In addition, the pyrolytically-obtained GO layer could likewise help to assist the CoPt and NiPt NPs.

In further analysis, as shown in Fig. S10 (ESI $\dagger$ ), the morphology of $\mathrm{Ni}_{0.8} \mathrm{Pt}_{0.2} / \mathrm{GO}$ and $\mathrm{rGO}, \mathrm{Co}_{0.8} \mathrm{Pt}_{0.2} / \mathrm{GO}$ and $\mathrm{rGO}$ was well preserved. Although some mixing was detected, which might be the reason for the slight decrease in the activity during the durability test, the TEM images of the recovered catalyst show no significant variation in the particles (Fig. S10c, $\mathrm{d}, \mathrm{ESI} \dagger)$. Moreover, there is a small change in the particle size and agglomeration is observed, signifying that the structure of the $\mathrm{Ni}_{0.8} \mathrm{Pt}_{0.2} / \mathrm{GO}$ and $\mathrm{rGO}, \mathrm{Co}_{0.8} \mathrm{Pt}_{0.2} / \mathrm{GO}$ and $\mathrm{rGO}$ NPs remains unchanged after usage. The $\mathrm{Ni}_{0.8} \mathrm{Pt}_{0.2} / \mathrm{GO}$ and $\mathrm{rGO}, \mathrm{Co}_{0.8} \mathrm{Pt}_{0.2} /$ GO and rGO catalysts demonstrate very high catalytic stability and durability towards $\mathrm{AB}$ hydrolytic dehydrogenation. In addition, Fig. S11 (ESI $\dagger$ ) shows the X-ray diffraction (XRD) pattern of the reused catalyst for $\mathrm{Ni}_{0.8} \mathrm{Pt}_{0.2} / \mathrm{GO}$ and rGO NPs. Obviously, in addition to the GO $\left(2 \theta=13.26^{\circ}\right)$ diffraction peak, only one broad diffraction peak at about $2 \theta=43.0^{\circ}$, representing the disappearance of rGO, was observed. This indicates that the $\mathrm{Ni}_{0.8} \mathrm{Pt}_{0.2} / \mathrm{GO}$ and rGO NPs have a low crystalline structure, as shown in Fig. $\mathrm{S} 11$ (ESI $\dagger$ ).

The aqueous $\mathrm{AB}$ solution catalytic efficiency was confirmed and studied at various temperatures in the range of $5-15^{\circ} \mathrm{C}$ starting with $\mathrm{Ni}_{0.8} \mathrm{Pt}_{0.2} / \mathrm{GO}$ and $\mathrm{rGO}$ and $100 \mathrm{mM} \mathrm{AB}$ in $10 \mathrm{~mL}$ of $\mathrm{H}_{2} \mathrm{O}$. As shown in Fig. 10A, the hydrogen generation rate steadily increased with increasing temperature and the TOF value reached the maximum at $15{ }^{\circ} \mathrm{C}$. Thus, the $\mathrm{Ni}_{0.8} \mathrm{Pt}_{0.2} / \mathrm{GO}$ and rGO catalyst was chosen in all the further experiments.

Based on the above presumptions and the consequences of the following investigations, a mechanism to explain the GO-AB cross-type nanostructure arrangement has been proposed, as shown in Fig. 11, which states that the GO nanosheets have their basal planes brightened with hydroxyl groups. These groups empower the proto analysis of the $\mathrm{B}-\mathrm{H}$ bond in a portion of the $\mathrm{AB}$ molecules, which were present in the middle of the isolated GO sheets. This causes the development of the cationic $\mathrm{AB}$ connected to the oppositely charged oxygen through electrostatic interactions (Fig. 11B). On the other hand, the other $\mathrm{AB}$ atoms are not protonated and circulated inside the interlayer space, and the GO sheets are inclined to restack to make a sandwiched $\mathrm{GO}-\mathrm{AB}-\mathrm{GO}$ structure as the dissolvable material is evacuated. $\mathrm{AB}$ and its cationic initiator moved towards becoming encapsulated inside the GO interlayer.

For the current metal-catalyzed reaction, the initiation procedure happens on the metal catalyst surface, as proposed by the zero-order kinetic reaction. A plausible mechanism is shown in Fig. 12. It proposes that there is an interface between the $\mathrm{AB}$ molecules and the metal particle surface that creates an initiated complex species in the rate-determining step, on which attack by a water molecule readily results in the deliberate separation of the $\mathrm{B}-\mathrm{N}$ bond and hydrolysis at the center of $\mathrm{BH}_{3}$ to form the borate ion together with $\mathrm{H}_{2}$ (eqn (1)). According to literature, without water, dehydrocoupling between the $\mathrm{AB}$ molecule occurs, which produces new B-N bonds, probably by means of a thorough connection in between, on the metal surface. ${ }^{46-50}$

\section{Conclusion}

In summary, we have developed graphene oxide supported transition metals NiCo, NiPt, and CoPt NPs catalysts that were essentially prepared using hydrothermal reactions at $180{ }^{\circ} \mathrm{C}$ for $5 \mathrm{~h}$ in an oven under the ambient atmosphere. The enhanced bimetallic $\mathrm{Ni}_{0.8} \mathrm{Pt}_{0.2} / \mathrm{GO}$ and $\mathrm{rGO}, \mathrm{Co}_{0.8} \mathrm{Pt}_{0.2} / \mathrm{GO}$ and
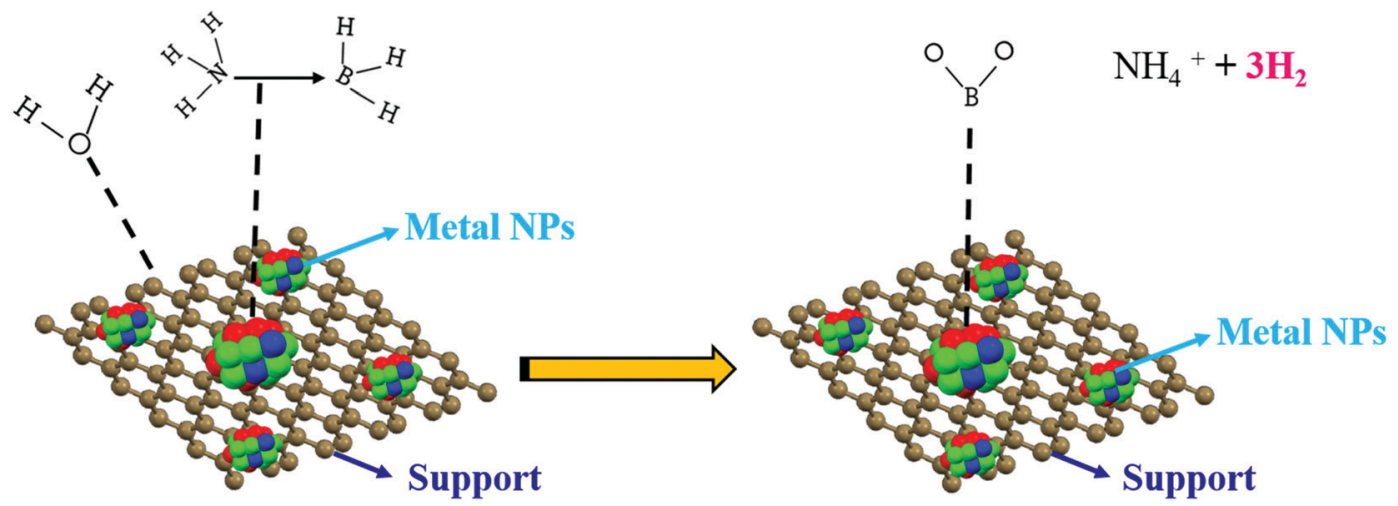

Fig. 12 The suggested mechanism for $A B$ catalytic dehydrogenation. 
rGO catalysts show incredible catalytic efficiency towards $\mathrm{H}_{2}$ generation from aqueous $\mathrm{AB}$ solution hydrolysis in association with their bimetallic supplements at $25{ }^{\circ} \mathrm{C}$ with a TOF value of $214.28 \mathrm{~min}^{-1}$ and $230.76 \mathrm{~min}^{-1}$, respectively, which are the highest values with respect to all of the GO and rGO-supported transition-metal catalysts ever studied for this reaction. The $\mathrm{Ni}-\mathrm{Pt}$ and $\mathrm{Co}-\mathrm{Pt}$ oxide maintenance can adsorb and break the B-H bonds in $\mathrm{BH}_{4}{ }^{-}$and weaken the $\mathrm{H}-\mathrm{O}$ bonds in $\mathrm{H}_{2} \mathrm{O}$ via the hydrogen generation electron transmission effect. The highly efficient $\mathrm{Co}_{0.4} \mathrm{Ni}_{0.6} / \mathrm{GO}, \mathrm{Co}_{0.9} \mathrm{Pt}_{0.1} / \mathrm{GO}$, and $\mathrm{Co}_{0.6} \mathrm{Ni}_{0.4} / \mathrm{GO}$ catalysts likewise show great catalytic efficiency for hydrogen generation from aqueous $\mathrm{AB}$ solution at $25{ }^{\circ} \mathrm{C}$. The catalysts also demonstrate the best recycling properties, with a conserved catalytic activity of about $98 \%$ after the seventh reaction cycle. This outstanding GO and rGO-supported transition metal heterogeneous catalyst activity demonstrates a promising methodology towards the improvement of $\mathrm{AB}$ as a plausible chemical hydrogen storage material for application in fuel cells. In addition, this technique can be effectively extended to the preparation of other graphene oxide-supported transition-metal modified methods for several other applications.

\section{Conflicts of interest}

The authors declare no competing financial interest.

\section{References}

1 L. L. Long, X. Y. Liu, J. J. Chen, J. Jiang, C. Qian, G. X. Huang and H. Q. Yu, ACS Appl. Nano Mater., 2018, 1, 6800-6807.

2 P. Z. Li, A. Aijaz and Q. Xu, Angew. Chem., Int. Ed., 2012, 51, 6753-6756.

3 L. Wang, H. Li, W. Zhang, X. Zhao, J. Qiu, A. Li and J. Zeng, Angew. Chem., Int. Ed., 2017, 56, 4712-4718.

4 Z. Li, T. He, D. Matsumura, S. Miao, A. Wu, L. Liu and P. Chen, ACS Catal., 2017, 7, 6762-6769.

5 H. Cheng, X. Qian, Y. Kuwahara, K. Mori and H. Yamashita, Adv. Mater., 2015, 27, 4616-4621.

6 A. Aijaz, T. Akita, N. Tsumori and Q. Xu, J. Am. Chem. Soc., 2013, 135, 16356-16359.

7 M. Nielsen, E. Alberico, W. Baumann, H. J. Drexler, H. Junge, S. Gladiali and M. Beller, Nature, 2013, 495, 85-89.

8 Q. Yao, Z. H. Lu, W. Huang, X. Chen and J. Zhu, J. Mater. Chem. A, 2016, 4, 8579-8583.

9 Q. Yao, Z. H. Lu, R. Zhang, S. Zhang, X. Chen and H. L. Jiang, J. Mater. Chem. A, 2018, 6, 4386-4393.

10 P. Lara, K. Philippot and A. Suárez, ChemCatChem, 2019, 11, 766-771.

11 A. Uzundurukan and Y. Devrim, Int. J. Hydrogen Energy, 2019, 44, 26773-26782.

12 H. Zhang, D. Ke, L. Cheng, X. Feng, X. Hou, J. Wang and S. Han, Prog. Nat. Sci.: Mater. Int., 2019, 29, 1-9.

13 K. Mori, K. Miyawaki and H. Yamashita, ACS Catal., 2016, 6, 3128-3135.

14 H. Ren and P. Cui, Front. Mater., 2019, 6, 223.
15 L. Luconi, U. B. Demirci, M. Peruzzini, G. Giambastiani and A. Rossin, Sustainable Energy Fuels, 2019, 3, 2583-2596.

16 R. M. Brooks, I. M. Maafa, A. M. Al-Enizi, M. M. El-Halwany, M. Ubaidullah and A. Yousef, J. Nanomater., 2019, 9, 1082.

17 P. Xi, F. Chen, G. Xie, C. Ma, H. Liu, C. Shao and Z. Zeng, Nanoscale, 2012, 4, 5597-5601.

18 L. Qian, D. Jia and Y. Miao, J. Electrochem. Soc., 2019, 166, F18-F23.

19 S. Oh, D. Song, H. Kim, D. Sohn, K. Hong, M. Lee and H. Kwon, J. Alloys Compd., 2019, 806, 643-649.

20 X. Yang, Q. Li, L. Li, J. Lin, X. Yang, C. Yu and C. Tang, J. Power Sources, 2019, 431, 135-143.

21 H. Göksu, Y. Yıldız, B. Çelik, M. Yazıcı, B. Kılbaş and F. Sen, ChemistrySelect, 2016, 1, 953-958.

22 N. Z. Shang, C. Feng, S. T. Gao and C. Wang, Int. J. Hydrogen Energy, 2016, 41, 944-950.

23 H. Can and O. Metin, Int. J. Hydrogen Energy, 2019, 44, 25642-25651.

24 J. M. Yan, X. B. Zhang, S. Han, H. Shioyama and Q. Xu, Angew. Chem., Int. Ed., 2008, 47, 2287-2289.

25 C. C. Hou, Q. Li, C. J. Wang, C. Y. Peng, Q. Q. Chen, H. F. Ye and Y. Chen, Energy Environ. Sci., 2017, 10, 1770-1776.

26 L. Hostert, E. G. Neiva, A. J. Zarbin and E. S. Orth, J. Mater. Chem. A, 2018, 6, 22226-22233.

27 Z. L. Wang, J. M. Yan, H. L. Wang, Y. Ping and Q. Jiang, J. Mater. Chem. A, 2013, 1, 12721-12725.

28 W. Wang, Z. H. Lu, Y. Luo, A. Zou, Q. Yao and X. Chen, ChemCatChem, 2018, 10, 1620-1626.

29 Y. H. Zhou, Z. Zhang, S. Wang, N. Williams, Y. Cheng, S. Luo and J. Gu, Int. J. Hydrogen Energy, 2018, 43, 18745-18753.

30 Y. Men, J. Su, X. Wang, P. Cai, G. Cheng and W. Luo, Chin. Chem. Lett., 2019, 30, 634-637.

31 Y. Men, J. Su, C. Huang, L. Liang, P. Cai, G. Cheng and W. Luo, Chin. Chem. Lett., 2018, 29, 1671-1674.

32 C. Wang, R. Ciganda, L. Yate, J. Tuninetti, V. Shalabaeva, L. Salmon and D. Astruc, J. Mater. Chem. A, 2017, 5, 21947-21954.

33 D. Sun, V. Mazumder, O. Metin and S. Sun, ACS Nano, 2011, 5, 6458-6464.

34 D. Sun, V. Mazumder, O. Metin and S. Sun, ACS Catal., 2012, 2, 1290-1295.

35 L. Yang, W. Luo and G. Cheng, ACS Appl. Mater. Interfaces, 2013, 5, 8231-8240.

36 Q. Yao, Z. H. Lu, Y. Yang, Y. Chen, X. Chen and H. L. Jiang, Nano Res., 2018, 11, 4412-4422.

37 J. Wang, X. B. Zhang, Z. L. Wang, L. M. Wang and Y. Zhang, Energy Environ. Sci., 2012, 5, 6885-6888.

38 X. Wang, D. Liu, S. Song and H. Zhang, J. Am. Chem. Soc., 2013, 135, 15864-15872.

39 X. Wang, D. Liu, J. Li, J. Zhen and H. Zhang, NPG Asia Mater., 2015, 7, 158.

40 Y. Long, J. Li, L. Wu, Q. Wang, Y. Liu, X. Wang and H. Zhang, Nano Res., 2019, 12, 869-875.

41 G. Chen, S. Sun, X. Sun, W. Fan and T. You, Inorg. Chem., 2009, 48, 1334-1338. 
42 F. Zhu, G. Chen, S. Sun and X. Sun, J. Mater. Chem. A, 2013, 1, 288-294.

43 X. Du, C. Liu, C. Du, P. Cai, G. Cheng and W. Luo, Nano Res., 2017, 10, 2856-2865.

44 X. Zhou, X. F. Meng, J. M. Wang, N. Z. Shang, T. Feng, Z. Y. Gao and C. Wang, Int. J. Hydrogen Energy, 2019, 44, 4764-4770.

45 Q. Yao, K. Yang, X. Hong, X. Chen and Z. H. Lu, Catal. Sci. Technol., 2018, 8, 870-877.
46 M. Mahyari and A. Shaabani, J. Mater. Chem. A, 2014, 2, 16652-16659.

47 Q. Xu and M. Chandra, J. Power Sources, 2006, 163, 364-370. 48 C. A. Jaska, K. Temple, A. J. Lough and I. Manners, J. Am. Chem. Soc., 2003, 125, 9424-9434.

49 C. A. Jaska and I. Manners, J. Am. Chem. Soc., 2004, 126, 9776-9785.

50 Q. Zhuo, Y. Zhang, Q. Du and C. Yan, J. Colloid Interface Sci., 2015, 457, 243-247. 